V. Andriiv, Dr. Sc. (Law), Prof.

Taras Shevchenko National University of Kyiv, Kyiv, Ukraine

\title{
INTERNATIONAL LEGAL PROTECTION OF LABOR RIGHTS OF DOMESTIC WORKERS
}

The article addresses the analysis of international legal acts that regulate the labor relations of domestic workers, as well as related problems. The peculiarities of such regulation and its characteristic features are determined.

Due to the fact that the problem of regulating the activities of employees who perform work on household services under the employment contract today is global in nature, it is relevant to many countries around the world concerning the basic standards and guarantees for those employed under the contract and engaged in housework. The means established by law to provide decent work conditions for domestic workers, as well as protection against discrimination, various forms of violence and interference in the privacy of domestic workers are determined.

The methodological basis of the study were general and special methods of cognition. The dialectical method examines the problems of legal regulation of international norms of employment of domestic workers and their relation to a number of trends that have different effects on international labor law. Formal-logical and systematic methods were used in the study of the content of international legal acts governing the employment of domestic workers.

The main result of the study is the regulation through international legal acts of relations concerned with the use of hired labor of domestic workers, improving its conditions, protection against discrimination and creating conditions for the free exercise of their ability to work within national laws as well as for comparative legal analysis and ways of existing systems improvement. Emphasis is also placed on increasing the role and need for recognition of legal mechanisms for the protection of labor rights of domestic workers, improvement of international legal norms aiming at their protection.

Keywords: domestic work, employee, employment contract, international legal acts, household, working conditions, legal protection.

Bulletin of Taras Shevchenko National University of Kyiv.

Legal Studies, 2021; 4 (119): 8-11

УДК 342.7

DOI: https:doi.org/10.17721/1728-2195/2021/4.119-2
ISSN 1728-2195

(C) Taras Shevchenko National University of Kyiv, Publishing center "Kyiv University", 2021

Я. С. Бабич, асп. ORCID ID: 0000-0002-3616-5515

Київський національний університет імені Тараса Шевченка, Київ, Україна

\section{СПІВВІДНОШЕННЯ ПОНЯТЬ "ПРАВОВИЙ ЗАХИСТ" ТА "ОХОРОНА ПРАВА" У НАУКОВОМУ ДИСКУРСІ}

Розглянуто й досліджено юридичні категорії "правовий захист" та "охорона права". Проаналізовано правову природу і зміст иих визначень. Особливу увагу приділено характеристикам цих дефініцій у науковій міжнародній і вітчизняній доктринах. Розглянуто позиції п'яти різних наукових шкіл щодо розуміння означених понять. Перша когорта науковців дотримується поглядів, за якими такі дефініції аналізуються як взаємодія частини та цілого. Друга група вчених ототожнює поняття "правовий захист" та "охорона права". Третій погляд на означену теоретичну проблематику полягає у розмежуванні окреслених визначень. Четверта плеяда науковців розкриває аналізовані категорії крізь призму окремих галузей права, зважаючи на предмет і метод правового регулювання кожної окремої сфери. Універсальний підхід розмежовує поняття "правовий захист" i "охорона права" й розглядає їх як різні та водночас абсолютно повноцінні юридичні категорії. Обґрунтовано, що останній має нормативно-прикладне значення й результативно використовується міжнародним співтовариством як на доктринальному, так і на законодавчому рівні. На підставі проведеного теоретичного дослідження запропоновано самостійні наукові висновки та судження з аналізованої тематики, зокрема надано авторське визначення дефініції "правовий захист". Крім того, виокремлено основні ознаки, притаманні вищезгаданим категоріям. Особливу увагу наголошено на необхідності виділення превентивної складової поняття "правовий захист", яка має особливо важливий характер у межах означеної категорії.

Ключові слова: правовий захист, охорона права, права людини, відновлення порушених прав, недопущення правопорушення, превентивний характер.

\section{ВСТУП}

Вирішення будь-якої правової дискусії потребує глибокого всебічного аналізу змісту основних понять, десрініцій, термінів і категорій. Пропоноване дослідження має на меті розв'язати постале завдання щодо співвідношення категорій "правовий захист" та "охорона права" бодай у науковій сфрері. Зростаючий останнім часом інтерес до означеної проблеми неодноразово привертав увагу вітчизняних і зарубіжних юристів. Кожен з авторів підкреслював ії актуальність і багатогранність. Комплексний підхід і прагнення розв'язати поставлені завдання вимагає від нас дослідити позиції наукових шкіл щодо розуміння згаданих понять.

Об'єктом цього наукового дослідження є юридичні категорії "правовий захист" та "охорона права".

Методологічною основою вказаної розвідки, з огляду на її комплексний характер, покладено загальнонауковий діалектичний метод пізнання суспільних явищ у їхньому взаємозв'язку та розвитку. Також застосовано спеціальні методи наукового пізнання, з-поміж них: формально-юридичний і логіко-юридичний.

\section{ОСНОВНІ РЕЗУЛЬТАТИ}

Для розв'язання означеної проблеми звертаємося до словника української мови, який у термін "захищати" вкладає такі значення: "оберігати, загороджувати, укривати кого-небудь або що-небудь від чогось шкідливого, небажаного, небезпечного" [1, с. 308]. Таке загальне тлумачення $€$ цілком прийнятне і дозволяє нам перейти до з'ясування сутності категорії "правовий захист".

Останній дефініції присвячено велику увагу дослідників у сорері права. Ї̈̈ зміст розкривається на сторінках низки монографій, статей, публікацій і підручників. Огляд та аналіз правничої літератури дає підстави стверджувати про існування п'яти кардинально різних позицій щодо розуміння сутності категорії "правовий захист". У них учені, подекуди, співвідносять поняття аналізованої категорії з розумінням дефініції "правова охорона".

До прибічників першого підходу можна віднести радянських теоретиків права, серед яких: В. Смолярчук, С. Гулунський, М. Строгович та С. Алєксєєв. Останній, зокрема, визначав "захист прав" як державно-примусову діяльність компетентних органів, яка спрямована на регенерацію права, яке було порушено. "Захист права спрямований, у першу чергу, на здійснення "відновлюва- 
льних" завдань і фрункцій держави - поновлення порушеного права та забезпечення юридичного обов'язку", зазначає дослідник [2]. Таким чином, простежується позитивістський підхід до розуміння права, який був притаманний радянській юридичній школі, адже в умовах тоталітаризму інші позиції не могли існувати. Разом із тим, запропоноване С. Алєксєєвим визначення стало класичним для теоретико-правової науки і довгий час дублювалося в різних навчальних посібниках.

Розвиток юридичної науки в умовах української незалежності довгий період перебував під впливом штампів попередньої епохи. Це простежується з наукових праць теоретиків права, які беззастережно рецепіюють наукові позиції радянських дослідників. Так, вітчизняні правознавці С. Булавіна, Т. Давидова, Ю. Желіховська зводять поняття "правовий захист" лише до поновлення порушеного права або відновлення втраченого права. "Захист прав - це засіб, який наступає за порушенням і тягне за собою відновлення відповідного суб'єктивного права", - пише у своїх розвідках Ю. Желіховська [3]. Питання співвідношення понять "правовий захист" та "охорона права" при цьому підході вирішується як взаємодія частини та цілого. Отже, охорона права вважається ширшим поняттям, яке включає в себе запобігання, недопущення правопорушень і поновлення прав і свобод у випадку посягання на них, тобто захист права. Останнє, своєю чергою, зводиться лише до випадків порушення прав.

Із запропонованим підходом важко погодитись, адже залишається поза увагою превентивна складова поняття "захист", яка $€$ особливо важливою. Вважаємо, що зміщення акцентів виключно на відновлення прав, у випадку їхнього порушення, є вузьким підходом і не вирішує частини проблем, що виникають на стадії запобігання і недопущення порушення таких прав.

Протилежного погляду дотримується плеяда інших вітчизняних учених, серед яких Г. Осетинська та П. Шумов [4]. Дослідники стоять на позиції, яку ми зараховуємо до другого підходу, ототожнення розуміння "охорона права" та "правовий захист". Аналізовані категорії розглядаються, як єдине ціле синонімічне поняття. "Охорона без захисту, як і захист без охорони, втрачає свій сенс, - наголошує П. Шумов, - оскільки незрозуміло, що охороняти" [4, с. 12]. Учені переконані, що їх не потрібно розривати і розглядати як самостійні юридичні явища.

Однак, такий підхід до співвідношення "правовий захист" та "охорона права" не всім науковцям видається переконливим та обґрунтованим. Так, є дещо інша, третя точка зору на зазначену теоретичну проблему. Вона полягає у розмежуванні аналізованих категорій. Таку думку висловив професор Київського національного університету імені Тараса Шевченка С. Вавженчук. "Не можна погодитись із тим, що у правовій сфері ці поняття $€$ тотожними та взаємозамінюваними", - наголошує дослідник [5, с. 47].

Далі українська дослідниця Н. Пархоменко, аналізуючи теоретико-правовий зміст понять і категорій, якими послуговується юридична наука, наголосила про відсутність між ними синонімів. Учена зазначила: "Хибність такого розуміння полягає в тому, що синонімічних понять не існує, адже є лише слова синоніми" [6, с. 53]. Таким чином, бачимо ґрунтовні докази, які заперечують факт ототожнення та синонімічного зв'язку між категоріями "правовий захист" та "охорона права". Поділяючи позиції останніх дослідників, вважаємо за доцільне означені поняття розмежовувати та розглядати як самостійні правові явища.

Четвертий підхід до осмислення змісту "правовий захист" сформувала плеяда науковців, які підійшли до визначення поняття через призму галузевого підходу. Так, дослідниця конституційного права О. Соколенко під "захистом прав" убачає "комплексну багатопланову інтегративну ознаку і водночас функцію держави, яка здійснюється крізь призму конструкцій демократичної, правової і соціальної держави, природного права та громадянського суспільства" [7]. Справді, забезпечення правового захисту $є$ обов'язком держави, який покладається на уповноважені органи. Останні мають вживати відповідні заходи у тих сферах суспільного життя, де може виникнути загроза порушення прав громадян. Тож, враховуючи визнання у демократичних країнах людини як найвищої соціальної цінності, захист прав особи, беззаперечно, можна вважати й ознакою, і функцією держави. Останні проголошуються в основних нормативноправових актах. Так, ст. 3 Конституції України визначає людину найвищою соціальною цінністю, а розділ II Основного закону присвячено правам і свободам громадян, які у тій чи іншій формі захищаються державою. Водночас, ми переконані, що захист як функцію варто розглядати не як суто декларативний намір, а як конкретний напрямок діяльності держави. Він закріплений нормативно-правовими актами за уповноваженими органами, 3 метою налагодження механізму означеної діяльності.

У такому руслі поняття "правовий захист" розглядає Т. Пащук. В основу своєї доктринальної праці дослідник заклав думку, що захистом прав людини є "правозастосовна та юрисдикційна діяльність державних компетентних органів, що спрямована на примусову реалізацію юридичного обов'язку, необхідного для реалізації права особи, на відновлення права або на попередження чи припинення такого порушення" [8]. Окремо вчений аналізує види юридичних засобів захисту, поділивши їх на дві групи: засоби державного і недержавного, тобто самостійного захисту. Така класифікація є важливою, адже вона демонструє, що захист - це не лише державна фрнкція. До нього також належать недержавні заходи захисту.

Представники цивілістичної школи Київського національного університету імені Тараса Шевченка, серед яких Ю. Притика, убачають у захисті прав юридичну діяльність, метою якої $є$ усунення перешкод на шляху реалізації суб'єктами своїх прав, а також припинення правопорушення, відновлення становища, яке існувало до моменту порушення [9]. Означений підхід має суб'єктивний характер, адже таким чином кожен учасник правовідносин наділяється можливістю усувати перешкоди, які не дозволяють йому реалізовувати власні права і таким чином самостійно захищати своє право. Публічна сфера захисту, з боку компетентних органів, тут відсутня.

Застосовуючи економіко-правовий підхід, М. Григорчук розглянув "правовий захист" як універсальну категорію, яка поширюється на економічну сферу, зокрема i на юридичних осіб - суб'єктів господарювання. "Правовий захист - це складний структурний елемент, який включає державно-примусову, юридичну та організаційно-практичну діяльність у законотворчій та економічній сфрерах, - зазначає дослідник, - він містить елементи судового, досудового, альтернативного (позасудового) видів захисту і самозахисту" [10]. Означений підхід $€$ виправданим для сфери господарювання, однак не розкриває можливості використання превентивних заходів захисту для унеможливлення порушення права. 
Проаналізовані думки дослідників щодо розуміння сутності "правовий захист", на нашу думку, містять вузький галузевий підхід і ефективно можуть спрацювати лише у конкретній сфрері. Так, учені конституціоналісти розглядають поняття "правовий захист" як важливу та невід'ємну функцію держави. Представники адміністративної сфери вбачають у ньому юрисдикційну діяльність державних органів. Цивілістична правова думка зводить означене поняття до особистого захисту учасника правовідносин шляхом усунення перешкод на шляху забезпечення прав і свобод. Економіко-правова сорера до розуміння аналізованої категорії включає і захист інтересів суб'єктів господарювання.

Погляди на категорію "правовий захист" галузевого характеру, які ми аналізували, важливі для нашого дослідження, адже лише таким чином можна досягнути комплексного результату. Однак, досліджувана проблематика потребує універсального підходу, який відкриє шлях для розуміння сутності категорії "захист населення від інфекційних хвороб", яка так чи інакше торкається всіх сфер суспільних відносин.

Представники такого підходу належать до п'ятої групи та репрезентують як вітчизняну, так і зарубіжну науку. Яскравими представниками останньої $є$ В. Тархов, В. Абрамов, А. Мордовець [11; 12; 13]. Дослідники розмежовують поняття "охорона права" та "захист права". Зокрема, перший учений стверджує, що охорона права діє на постійній основі й має на меті забезпечити здійснення такого права, а також недопущення його порушення. "Охорона забезпечується державою, яка встановлює та закріплює суб'єктивні права громадян, а також їхній захист, - пише В. Тархов, - проте носій права може самостійно вжити різних заходів охорони своїх інтересів, наприклад потурбуватися про охорону власних речей, забезпечити доказами кредиторські права (документи, свідки тощо)" [11]. Відтак, необхідність вдатися до захисту права виникає не лише у випадку його порушення, оспорювання, а й у разі виникнення загрози такого порушення.

Своєю чергою А. Мордовець розглядає поняття "охорона права" через призму реалізації прав і свобод, які перебувають під контролем соціальних інститутів. Такий контроль відбувається автономно, без їхнього безпосереднього втручання. Захист прав, на думку дослідника, застосовується лише тоді, коли права особи ще не порушені, проте їхня фрактична реалізація - під загрозою. "Якщо $є$ факт порушення, то необхідно не захищати права, а відновлювати їх", - стверджує дослідник [13, с. 88]. Такий підхід заслуговує на особливу увагу, адже при порушенні права важливим $є$ його поновлення. Захист, натомість, має спрацьовувати на стадії виникнення реальної загрози порушення права.

У подібній тональності висловлено думки і вітчизняних дослідників, серед яких І. Зубач, С. Чорна, Т. Волошанівська. Вони запропонували універсальний підхід розмежування поняття "охорона права" та "захист права" [14]. Т. Волошанівська, зокрема, була достатньо переконливою при обґрунтуванні поняття "захист прав", під яким розуміла діяльність щодо застосування заходів із припинення порушення права або попередження такого порушення у випадку існування відповідної загрози. Авторка вдало акцентувала увагу, що основною ознакою правового захисту є підстава його виникнення - порушення права особи або конкретна загроза його порушення.
Ми поділяємо означений підхід і вважаємо за доцільне розмежовувати категорії "правовий захист" та "охорона права". Остання має загальносуспільний характер і контролюється соціальними інститутами. Перша має нормативно-прикладне значення й успішно використовується світовою спільнотою в міжнародних і вітчизняних нормативно-правових актах [15]. Під ним убачаємо комплексну самостійну правову категорію, яка включає в себе сукупність державних і недержавних (самостійних) заходів відновлювального і превентивнопопереджувального характеру, 3 метою поновлення, компенсації або недопущення порушення прав, свобод i притягнення винних осіб до юридичної відповідальності.

Сформульоване визначення дозволило нам виокремити такі ознаки досліджуваної категорії: до першої належить нормативність, яка полягає у відтворенні в міжнародних приписах, національних законодавчих i підзаконних нормативно-правових актах. Загальнообов'язковість - це друга ознака, яка полягає у невід'ємній дієвості приписів і норм, котрі регламентують захист прав у тих сорерах суспільного життя, де вони потрібні. Третьою ознакою $є$ обумовленість, яка демонструє наявність причино-наслідкового зв'язку між загрозою порушенням прав і свобод чи посяганням на них і безпосередньо захистом. Реституційність - це четверта ознака, яка забезпечує поновлення, компенсацію за порушення відповідних прав і свобод. Захист прав також має санкційний характер, тобто передбачає настання негативних наслідків у разі порушення відповідних прав і притягнення винуватих осіб до юридичної відповідальності. Така ознака дозволяє забезпечити недопущення порушення права загалом.

\section{ВИСНОВКИ}

Отже, дефініція "правовий захист" та ії співвідношення з категорією "правова охорона" не втрачала своєї актуальності як за радянських часів, так і серед сучасних дослідників. Зміст цих понять розкривається на сторінках багатьох юридичних розвідок. Аналіз наукової літератури дає можливість засвідчити наявність п'яти відмінних позицій щодо розуміння сутності та співвідношення категорій "правовий захист" та "охорона права". Так, перша плеяда вчених притримується поглядів, за якими ці дефініції розглядаються як взаємодія частини та цілого. Друга група науковців ототожнює категорії "правовий захист" та "охорона права". Третій погляд на означену теоретичну проблему полягає у розмежуванні аналізованих дефініцій. Четвертий підхід надає змогу розкрити аналізовані категорії з погляду окремих юридичних галузей, враховуючи предмет і метод правового регулювання кожної окремої галузі. Останній - універсальний підхід, який ми підтримуємо цілком і повністю, розмежовує дефініції "правовий захист" і "охорона права" й розглядає їх як окремі повноцінні юридичні категорії. Адже "охорона права" передбачає загальносуспільний характер і контролюється соціальними інститутами, у той самий час перша категорія - "правовий захист" - має нормативно-прикладне значення й успішно застосовується міжнародною спільнотою в нормативно-правових актах права загалом.

Список використаних джерел:

1. Словник української мови : [в 11 т.] / АН Української РСР, Ін-т мовознав. ім. О. О. Потебні ; редкол.: І. К. Білодід (голова) [та ін.]. Київ : Наук. думка, 1970 - 1980. Т. 3 : 3 / ред. тому: Г. М. Гнатюк, Т. К. Черторизька. $1972.744 \mathrm{c.}$

2. Алексеев С.С. Общая теория права. Т.1. М.: Юридическая литература, 1981. 359 с. 
3. Желіховська Ю.В. Співвідношення та розмежування понять "охорона та захист" / Науковий вісник міжнародного гуманітарного університету. Серія: Юриспруденція. 2015. № 13 Том 2. с. 18-21.

4. Шумов П.В. Соотношение понятий "защита" и "охрана" информационных прав / П.В. Шумов // Уголовно-исполнительная система: право, экономика, управление. 2013. № 5. С. 12-14.

5. Вавженчук С. Я. Співвідношення понять "захист" та "охорона" трудових прав в чинному законодавстві / С. Я. Вавженчук // Форум права. 2010. № 1. С. 45-49.

6. Пархоменко Н. М. Джерела права: проблеми теорії та методології: [монографія] / Інститут держави і права ім. В. М.Корецького НАН України / Н. М. Пархоменко. К.: Юридична думка, 2008. 335 с.

7. Соколенко О. Л. Захист прав громадян як основна функція правової держави / О. Л. Соколенко // Часопис Київського університету права. 2013. № 2. С. 118-121.

8. Пашук T.І. Право людини на ефективний державний захист їі прав та свобод : дис... канд. юрид. наук: 12.00 .01 / Львівський національний ун-т ім. Івана Франка. Л., 2006

9. Притика Ю. Д. Поняття і диференціація способів і захисту цивільних прав та інтересів // Вісник Київського національного університету імені Тараса Шевченка. 2004. № 60-62. С. 16-19.

10. Григорчук М. В. Захист прав та охоронюваних законом інтересів суб'єктів господарювання: матеріальний і процесуальний аспекти / Теорія і практика правознавства. 2017. Вип. 1(11). С. 1-13.

11. Абрамов В.И. Права ребенка и их защита в России: общетеоретический анализ: дис. ... д-ра юрид. наук. Саратов, 2007. 455 с.

12. Тархов В. А. Гражданское право: общая часть : курс лекций под ред. В. А. Рыбакова. - Чебоксары : Чувашское книжное изд-во, 1997. 331 c.

13. Мордовец АС. Социально-юридический механизм обеспечения прав человека и гражданина. Саратов, 1996.

14. Зубач І. М. Функція захисту у сучасному кримінальному провадженні України / І. М. Зубач // Вісник Національного університету "Львівська політехніка". Юридичні науки. 2014. № 810. С. 178-183.

15. Волошанівська Т.В. Щодо питання розмежування понять "захист" та "охорона" у кримінальному провадженні в світлі міжнародних стандартів прав людини // Юридичний науковий електронний журнал. № 6. 2016. с. $216-220$.

\section{References:}

1. Bilodid I.K. (1972). Slovnyk ukrai'ns'koi' movy [Dictionary of the Ukrainian language]. Kyi'v : Naukova Dumka.

2. Alekseev S.S. (1981). Obshhaja teoryja prava [General theory of law]. T.1. M.: Jurydycheskaja lyteratura [Legal literature], 1981.

3. Zhelihovs'ka Ju.V. (2015). Spivvidnoshennja ta rozmezhuvannja ponjat' "ohorona ta zahyst" [Correlation and delimitation of the concepts of "protection and defense"]. Naukovyj visnyk mizhnarodnogo gumanitarnogo universytetu. Serija: Jurysprudencija. [Scientific Bulletin of the International Humanities University. Series: Jurisprudence]. № 13. Vol. 2. p.18-21.

4. Shumov P.V. (2013). Sootnoshenye ponjatyj "zashhyta" y "ohrana" ynformacyonnyyh prav [The relationship between the concepts of "protection" and "protection" of information rights]. Ugolovno-yspolnytel'naja systema: pravo, ekonomyka, upravlenye [Penitentiary system: law, economics, management]. № 5. p. 12-14

5. Vavzhenchuk S. Ja. (2010) Spivvidnoshennja ponjat' "zahyst" ta "ohorona" trudovyh prav $v$ chynnomu zakonodavstvi [The ratio of the concepts of "protection" and " defense" of labor rights in current legislation]. Forum prava [Forum of law]. № 1. p. 45-49.

6. Parhomenko N. M. (2008) Dzherela prava: problemy teorii' ta metodologii'. [Sources of law: problems of theory and methodology]. Instytut derzhavy i prava im. V. M.Korec'kogo NAN Ukrai'ny [Institute of State and Law. VM Koretsky NAS of Ukraine]. K.: Jurydychna dumka [Legal opinion], $335 \mathrm{p}$

7. Sokolenko O. L. (2013) Zahyst prav gromadjan jak osnovna funkcija pravovoi' derzhavy. [Protection of citizens' rights as the main function of the rule of law]. Chasopys Kyi'vs'kogo universytetu prava [Journal of Kyiv University of Law].№ 2. p. 118-121.

8. Pashuk T.I. (2006) Pravo ljudyny na efektyvnyj derzhavnyj zahyst 'i' prav ta svobod : dys... kand. juryd. Nauk [The human right to effective state protection of its rights and freedoms]: L'vivs'kyj nacional'nyj un-t im. Ivana Franka [Ivan Franko National University of Lviv]. L., 2006.

9. Prytyka Ju. D. (2004) Ponjattja i dyferenciacija sposobiv i zahystu cyvil'nyh prav ta interesiv [The concept and differentiation of methods and protection of civil rights and interests]. Visnyk Kyi'vs'kogo nacional'nogo universytetu imeni Tarasa Shevchenka [Bulletin of the Taras Shevchenko National University of Kyiv].№ 60-62. p. 16-19.

10. Grygorchuk M. V. (2017) Zahyst prav ta ohoronjuvanyh zakonom interesiv sub'jektiv gospodarjuvannja: material'nyj i procesual'nyj aspekty [Protection of rights and legally protected interests of business entities: material and procedural aspects]. Teorija i praktyka pravoznavstva [Theory and practice of jurisprudence]. Issue. 1 (11). p. 1-13

11. Abramov V.Y.(2007) Prava rebenka y yh zashhyta $\vee$ Rossyy: obshheteoretycheskyj analyz: dys. ... d-ra juryd. nauk [The rights of the child and their protection in Russia: general theoretical analysis: dis. ... Dr. Jurid. Science]:. Saratov. $455 \mathrm{p}$.

12. Tarhov V. A. (1997) Grazhdanskoe pravo: obshhaja chast' : kurs lekcy] [Civil law: the general part: a course of lectures] / pod red. V. A. Rybakova. - Cheboksary : Chuvashskoe knyzhnoe yzd-vo [Chuvash Book Publishing House]. $331 \mathrm{p}$.

13. Mordovec A.S. (1996) Socyal'no-jurydycheskyj mehanyzm obespechenyja prav cheloveka y grazhdanyna [Socio-legal mechanism for ensuring human and civil rights]. Saratov.

14. Zubach I. M. (2014) Funkcija zahystu u suchasnomu kryminal'nomu provadzhenni Ukrai'ny [Function of protection in modern criminal proceedings of Ukraine]. Visnyk Nacional'nogo universytetu "L'vivs'ka politehnika". Jurydychni nauky [Bulletin of the National University "Lviv Polytechnic". Legal sciences.]. № 810. p. 178-183.

15. Voloshanivs'ka T.V. (2016) Shhodo pytannja rozmezhuvannja ponjat' "zahyst" ta "ohorona" u kryminal'nomu provadzhenni v svitli mizhnarodnyh standartiv prav ljudyny [On the issue of distinguishing between the concepts of "protection" and "defense" in criminal proceedings in the light of international human rights standards]. Jurydychnyj naukovy] elektronnyj zhurnal [Legal scientific electronic journal]. № 6. p. 216-220.

Received: $18 / 09 / 2021$

1st Revision: 05/10/2021

Accepted: $20 / 10 / 2021$

Ya. Babych, PhD Student

Taras Shevchenko National University of Kyiv, Kyiv, Ukraine

\section{RELATIONSHIP OF CONCEPTS "LEGAL PROTECTION" AND "PROTECTION OF RIGHTS" IN SCIENTIFIC DISCOURSE}

The article addresses the understanding of the legal categories "legal protection" and "protection of rights". The legal nature and content of these definitions are analyzed. Particular attention is paid to the characteristics of these definitions in scientific international and domestic doctrines. The positions of five different scientific schools on the understanding of these concepts are considered. The first cohort of scientists adheres to the views according to which such definitions are analyzed as interaction of whole and part. The second group of scholars identifies the concepts of "legal protection" and "protection of rights". The third point of view on the specified theoretical problems, consists of the delimitation of the outlined definitions. The fourth constellation of scholars reveals the analyzed categories through the prism of individual branches of law, taking into account the subject and method of legal regulation of each area. The universal approach distinguishes between the concepts of "legal protection" and "protection of rights" and considers them as different, but at the same time absolutely full-fledged legal categories. It is substantiated that the latter has normative and applied significance and is effectively used by the international community both at the doctrinal and legislative levels. On the basis of the conducted theoretical research the independent scientific conclusions and judgments on the analyzed subjects are offered, in particular the author's definition of definition "legal protection" is given. In addition, the main features inherent in the above categories are highlighted. Particular attention is paid to the need of highlighting the preventive component of the concept of "legal protection", which is particularly important within this category.

Keywords: legal protection, human rights, restoration of violated rights, prevention of offenses. 